\title{
PARTNERSKÁ SPOKOJENOST ŽEN PRACUJÍCÍCH V AKADEMICKÝCH POVOLÁNÍCH
}

\author{
Veronika Očenášková, Irena Sobotková
}

\begin{abstract}
Abstrakt
Článek se zabývá partnerskou spokojeností žen, které pracují v akademických povoláních. Jeho základem je jedna z částí rozsáhlejšího výzkumného projektu. Hlavním cílem zde prezentované části výzkumu je zmapovat míru, aspekty a subjektivně důležité oblasti partnerské spokojenosti žen. Také byl zkoumán subjektivní pohled žen na partnerské přizpůsobení a kvalita vztahu v kontextu jejich náročné profese. Z hlediska výzkumného designu byla použita tzv. souběžná vnořená strategie $\mathrm{s}$ těžištěm v kvalitativní metodologii (Cresswell, 2003). Hlavní metodou sběru dat byl polostrukturovaný rozhovor doplněný kvantitativní metodou Škála partnerského přizpůsobení. Výzkumný soubor tvoří 32 žen ve věku 30-52 let, které se věnují akademické profesní dráze tř̌i a více let a žijí minimálně 3 roky v trvalém partnerském vztahu. Dílčí výsledky výzkumu ukazují, že ženy spokojené v partnerství mají stejné hodnoty, způsob uvažování a zájmy jako jejich partner. Partnery spojuje vzájemný respekt a oboustranná snaha o kompromis. Mezi negativní aspekty partnerské spokojenosti patř́ především nepřijetí profesního úspěchu partnerem, nadměrný individualismus a dominance na straně ženy a negativní události v životě partnerů. Vzhledem k naléhavosti zkoumané problematiky mohou být naše výzkumná zjišsění užitečná např́iklad pro poradenské psychologické služby poskytované obdobně pracovně vytíženým ženám.
\end{abstract}

Klíčová slova: ženy pracující v akademickém povolání, partnerská spokojenost, gender, dvoukariérové manželství

\section{PARTNERSHIP SATISFACTION OF WOMEN WITH ACADEMIC CAREERS}

\section{Abstract}

The article examines the level of partnership satisfaction of women working in academia. It is based on part of a wider-ranging research project. The main aim of the research presented here is to examine the degree of satisfaction in existing partnerships, its components and those areas of partnership satisfaction which are subjectively perceived as important. Moreover, the study explores the subjective opinion of women on adjustment in their partnership and on the overall relationship quality as judged by their demanding occupation. As far as the research design is concerned, a concurrent nested strategy was used with an emphasis on qualitative methodology (Cresswell, 2003). The main methods of data collection were semistructured interviews, supplemented by a quantitative Dyadic Adjustment Scale. The research sample consisted of 32 women aged between 30 and 52, who have been working in academia for a minimum of three years and who have been living in a stable relationship for at least 3 years. Partial results show that women who are satisfied in their partnership share the same values, way of thinking and interests with their partner. Factors such as mutual respect and striving to find a compromise produce a positive impact on the relationship. The negative aspects of partnership satisfaction include a critical inability to accept the career success by the partner, excessive individualism and domination on the side of the woman and negative incidents in the life of partners. As the researched theme is highly topical, the results obtained may assist in further developing psychological consulting aimed towards women with similarly demanding occupations.

Keywords: women in academia, partnership satisfaction, gender, dual career marriage

Došlo do redakce: 18. 1. 2014

Schváleno k publikaci: 18. 8. 2014 


\section{Úvod}

Dosavadní výzkumy dotýkající se zkoumané problematiky jsou především sociologické a zaměřují se na genderové otázky a rodinnou politiku. V roce 2013 jsme uskutečnili rozsáhlý výzkumný projekt, který se zabýval partnerskou a profesní spokojeností žen v akademických povoláních a problematikou harmonizace jejich pracovního a osobního života. Podnětem k realizaci výzkumu byl mimo jiné fakt, že psychologické výzkumy tohoto společensky aktuálního tématu dosud chyběly. Tento článek přináší výsledky jen určité části výzkumu. Naší snahou bylo porozumět pohledu žen pracujících na českých státních vysokých školách a na výzkumných pracovištích na jejich partnerskou spokojenost a různé aspekty související s kvalitou jejich vztahu.

Akademické povolání pro tyto ženy často znamená přenést se přes mnohá úskalí i předsudky a překonat překážky, které si člověk neznalý akademického povolání často ani neuvědomuje. Ženy se potýkají se stereotypním chápáním akademického světa jako typicky mužského, věnují se náročné výzkumné, publikační a pedagogické činnosti, mnoha organizačním aktivitám včetně obsáhlé administrativy. Jejich pracovní nasazení, zahrnující běžně i práci ve volném čase o víkendech a o dovolené, však není adekvátně finančně ohodnoceno. Akademické prostředí navíc vyžaduje neustálé přizpůsobování se změnám a nárůstu požadavků. Práce v oblasti vědy a výzkumu dnes představuje i poměrně vysoký stupeň nejistoty ohledně budoucnosti.

\section{Proměna a konflikt rolí u profesně vytížených žen}

V současnosti dochází k markantní proměně ženské a mužské role ve smyslu symetrizace, stírání rozdílů a vzájemné zastupitelnosti. Této problematice se věnují genderové studie, představitelé feminismu (Decarli Valdrová et al., 2004) i autoři, kteří se k feminismu neřadí (Harmut, 2006). Dokladem těchto proměn je např́klad existence dvoukariérových partnerství, která jsou poměrně frekventovaným tématem sociologického i psychologického výzkumu (Gilbert, 1993; Rapoport, Rapoport, 1976). Ve dvoukariérových partnerstvích se žena i muž intenzivně věnují své práci a dalšímu postupu $\mathrm{v}$ oboru a současně se snaží skloubit své zaměstnání s péčí o rodinu a děti (Benokraitis, 2012; Hakim, 2000). Jde tedy o alternativu k tradičnímu pojetí rodiny a genderových rolí. Jak ale potvrzují závěry M. Čermákové, H. Maříkové, J. Šanderové a M. Tučka (2000), muži stále upřednostňují tradiční pojetí role ženy jako matky a hospodyně. Ženy mají sice větší možnosti seberealizace, ale obvykle pocit'ují nutnost zvládat dobře povinnosti vyplývající z pracovní i rodinné role. Muži více lpí na genderových stereotypech, mnozí se jen obtížně vzdávají svých výsad (Dudová, 2006).

Úspěšná profesní dráha, resp. kariéra ženy byla v našich podmínkách dlouho spojena s negativní konotací a asociována s „kariérismem“ (viz také Křŕžková, Helšusová, 2002). A. Křížková (2002) ve své případové studii věnované ženám - manažerkám uvádí, že tyto ženy raději nemluví o svých pracovních úspěších s manželi, a sice proto, aby nenarušily partnerovu představu o přirozenosti nastavení genderových vztahů.

Podle J. Bierzové (2006) jsou životní volby žen diferencovány především podle vzdělání a podle přítomnosti dětí. Čím je žena vzdělanější, tím více se orientuje i mimo rodinu a naopak. Nároky spojené s profesí na jedné straně a kvalita partnerského vztahu a spokojenost s ním na straně druhé se u profesně vytížených žen vzájemně složitě ovlivňují. M. Vohlídalová (2006) došla k závěru, že $\mathrm{v}$ rámci časově náročných profesí jsou to právě ženy pracující na pozici vědeckých a odborných duševních pracovníků, které uvádějí jako nejčastější důvod rozchodu s partnerem vlastní profesní život. Konflikt mezi nároky vyplývajícími z pracovní a osobní, resp. rodinné oblasti je označován jako rolový konflikt. V literatuře se vyskytuje hlavně ve dvou podobách: jako konflikt práce rodina (work - family conflict, WFC), jehož zdrojem jsou pracovní nároky zasahující do rodinného života, a jako konflikt rodina - práce (family - work conflict, FWC), kdy rodinné povinnosti 
znesnadňují plnění pracovních úkolů (Gareis, Barnett, Ertel, Berkman, 2009; Netemeyer, Boles, McMurrian, 1996; Voydanoff, 2005). Související problematika rovnováhy mezi prací a osobním životem, tzv. work - life balance, byla u nás zkoumána především sociology v souvislosti $\mathrm{s}$ budováním kariéry $\mathrm{v}$ profesích náročných časově i z hlediska pracovního nasazení, kam autoři řadí i akademická povolání (Šaldová, 2007; Tupá, 2007; Vohlídalová, 2011). Z psychologů se rovnováhou základních životních oblastí jako jeden z prvních zabýval slovenský psycholog $\mathrm{P}$. Gröpel (Gröpel, 2006, 2007; Gröpel, Dovičovičová, 2012; Gröpel, Kuhl, 2009). Proces vedoucí k rovnováze obou hlavních životních oblastí je označován jako slad’ování, skloubení či harmonizace práce a osobního, resp. rodinného života (např. Cermáková, Hašková, Křižková, Linková, Maříková, 2002).

Jak ukazují nejnovější studie u nás realizované především Sociologickým ústavem Akademie věd, akademická profese představuje výrazné časové, ale i psychické a rolové zatížení (Červinková, 2007; Havelková, 2007; Linková, 2007; Šaldová, 2007; Tupá, 2007; Vohlídalová, 2011). Nároky vyplývají především z té skutečnosti, že očekávání od vzdělaných žen jsou protikladná: měly by být oddány práci stejně jako muži a současně by v duchu tradic měly upřednostňovat rodinu (Coser, Rokoff, 1971). Ačkoli je pracovní doba v akademické sféře flexibilní, tlak na výkon sílí a ženy běžně pracují, jak již bylo řečeno, i ve svém volnu. Přispívá k tomu i nutnost neustále se vzdělávat. Socioložka M. Linková (2007) upozorňuje, že i čas strávený s dítětem doma znamená pro ženu pracující v akademické oblasti vlastně jakýsi nežádoucí výpadek. O zásazích tohoto typu práce do soukromého života se zmiňují mnohé další autorky (Červinková, 2007; Linková, 2007; Šaldová, 2007). Pro tyto ženy je nepochybně velmi obtížné být úspěšné v práci i v soukromí. Jak uvádí M. Vohlídalová (2011), ženy stojí mezi dvěma odlišnými systémy hodnot. Na úspěšnou akademickou dráhu ženy lze tedy pohlížet jako na významný posun v možnostech její seberealizace, zároveň však také jako na možný zdroj rolového konfliktu a konfliktu s partnerem.

\section{Partnerská spokojenost}

Úspěch partnerského vztahu bývá psychology často měřen pomocí dvou ukazatelů. Stabilita vztahu hodnotí funkčnost a neporušenost partnerství. Druhým indikátorem je partnerská spokojenost, která zahrnuje subjektivní vnímání vztahu, pokud jde o konflikty, spokojenost, oddanost partnerovi a pocit štěstí (Benokraitis, 2012; Stanley, 2007).

Jeden z modelů partnerské spokojenosti nabízí C. Rusbultová (1991, 1993). Podle C. Rusbultové a jejich kolegů (1991) partnerská spokojenost pozitivně koreluje s tzv. partnerským přizpůsobením (accommodation), které je vymezeno dvěma dimenzemi: konstruktivním/ destruktivním a aktivním/ pasivním chováním. Na základě uvedených dimenzí byly stanoveny čtyři typy odpovědi partnera na destruktivní chování protějšku: vyjádření se (voice), opuštění (exit), loajalita (loyalty) a zanedbání (neglect). Vyjádření se je aktivní strategie s konstruktivním záměrem zlepšit podmínky ve vztahu prostřednictvím společné diskuze o problému, hledání řešení, či vyhledání odborné pomoci. Opuštění je aktivně destruktivní strategie, která partnerskému vztahu škodí např́íklad vzájemným osočováním, odloučením od partnera, či rozvodem partnerů. Loajalita s partnerem je pasivní forma konstruktivní strategie projevující se optimistickým náhledem na zlepšení vztahu, například nadějí na zlepšení, odpuštěním a vědomým zapomínáním křivd. Zanedbání vede k pasivnímu ohrožení partnerského vztahu prostřednictvím ignorace, vyhýbání se partnerovi zejména v otázce řešení společných problémů a diskutování o nich. Konstruktivní chování predikuje spokojenost ve vztahu, zatímco destruktivní chování předvídá nespokojenost ve vztahu. Tato kauzalita platí i v opačném směru: pokud jsou partneři spokojeni se svým vztahem, budou s větší pravděpodobností reagovat vyjádřením se a loajalitou, pokud jsou však v partnerském vztahu nespokojeni, bude vzájemná reakce destruktivní, partneři budou mít tedy tendenci unikat ze vztahu, či jej zanedbávat. 
G. B. Spanier (1976, 2001) přichází s koncepcí partnerského přizpůsobení (dyadic adjustment), na základě které zkonstruoval v roce 1976 hojně používaný nástroj k měření jeho jednotlivých komponent ${ }^{1}$. Jeho teorie vychází $\mathrm{z}$ předpokladu existence čtyř nezávislých dimenzí partnerského přizpůsobení: shoda v důležitých otázkách manželského fungování, partnerská spokojenost, partnerská soudržnost a vyjadřování emocí v partnerském vztahu.

N. Benokraitisová (2012) hovoří o partnerské spokojenosti u dlouholetých párů a vypočítává charakteristiky, které tyto dvojice spojují: vzájemný respekt, společné cíle, podporující partner, zaměření na komunikaci a řešení problémů. Autorka si všímá také souvislosti mezi partnerskou spokojeností a shodou mezi partnery. V tomto kontextu uvádí, že podle výzkumů jsou spolu št’astní př́edevším lidé $\mathrm{s}$ podobnými postoji, hodnotami, přesvědčeními a pocházející z podobného sociálního prostředí ve smyslu etnicity, socioekonomického statusu, víry i vzdělání. Podobnost mezi partnery snižuje pravděpodobnost osobnostních rozdílů, které mohou vést ke vzniku konfliktů a neshod. V naší odborné literatuře zdůraznil význam podobnosti hodnot a životních postojů ve funkčním manželství především I. Plaňava (1994). Společné trávení volného času však není zárukou spokojeného partnerství. Ženy mají tendenci přizpůsobovat se volnočasovým aktivitám muže, což vztahu spíše škodí.

Podle D. H. Olsona a A. K. Olsonové (2000) je ve vztahu dvou osob důležité př̌ekonávání rozdílů. Lidé spokojení v partnerském soužití jsou přizpůsobivější a více ochotni ke kompromisům než ti, kteří se snaží partnera ovládat a trvat na svých stanoviscích. Spokojení partneři jsou především dobrými přáteli, důvěrně se znají a jsou si lidsky blízcí. Proto jsou překotná manželství uzavřená $\mathrm{v}$ období romantické fáze vztahu náchylná $\mathrm{k}$ rozpadu především pro nereálná očekávání, malou míru emoční podpory, sníženou schopnost řešit problémy a nedorozumění (Benokraitis, 2012).

\section{Partnerská spokojenost profesně vytížených žen}

Naprostá většina studií na toto téma má kvantitativní výzkumný design a komparativní charakter a týká se dvoukariérových partnerství. Zpravidla vychází, že dvoukariérová partnerství zatížená pracovním stresem vykazují menší míru partnerské spokojenosti než partnerství, ve kterých se profesní dráze věnuje pouze jeden z partnerů (Minnotte, Minnotte, Pedersen, Mannon, Kiger, 2010; Yogev, 1982). A. Hochschildová a A. Machungová (2012) uvádějí, že ženy pracující v povoláních náročných na čas i energii nebývají př́liš v partnerství spokojené a častěji se rozhodují pro rozvod či odloučení. Př́ičinou je především skutečnost, že žena je schopna sama vydělávat peníze, být nezávislá, má pozitivní sebepojetí a více od muže očekává. V rodině s dětmi ji totiž čeká tzv. druhá směna, v níž je asistence partnera téměř nezbytná. J. Mullen, E. Kelley a E. K. Kelloway (2008) v souvislosti s profesním zahlcením popisují, že zásahy pracovního života do osobní sféry ${ }^{2}$ se projevují zvýšeným stresem a nespokojeností v rodině, v extrémních případech dlouhodobého působení pracovního stresu dokonce i rozpadem rodiny. Z pohledu genderu je negativním vlivem konfliktu práce - rodina více ohrožena partnerská spokojenost žen, zejména pro již zmíněnou mnohočetnost jejich rolí (Mullen, Kelley, Kelloway, 2008; Yogev, 1982).

\footnotetext{
${ }^{1}$ Revize této metody (Dyadic Adjustment Scale) je použita i v našem výzkumu. Bližší popis nástroje je uveden v části věnující se metodologii výzkumu.

${ }^{2}$ Tzv. work - family conflict (WFC).
} 
K. Minnotte et al. (2010) zkoumali ovlivnění partnerské spokojenosti konfliktem práce - rodina a př́slušnou genderovou ideologii ${ }^{3}$ u dvoukariérových partnerství. Ukázalo se, že tradiční postoj ke genderovým rolím pozitivně souvisí s partnerskou spokojeností žen a zmírňuje dopad konfliktu práce - rodina. Ženy zastávající rovnocenné genderové role dosahovaly nižší spokojenosti i tehdy, když konflikt práce - rodina prožívaly jen v malé míře. Negativní efekt konfliktu práce - rodina na partnerskou spokojenost se u těchto žen projevoval mnohem silněji než u žen zastávající tradiční stanovisko. D. Hall (1972) a L. L. Holmstromová (1972) ale naopak potvrdili větší míru sdílení, radosti a také partnerské spokojenosti u těchto párů. J. Mullen, E. Kelley a E. K. Kelloway (2008) konstatují, že profesní spokojenost je velmi úzce spjata se spokojeností v partnerství a s pozitivně prožívaným rodičovstvím. Ch.-Y. S. Lee a W. J. Doherty (2007) ve svém kvantitativním výzkumu zkoumali, do jaké míry je spokojenost v partnerství ovlivněna časovou náročností profese ženy a zapojením partnera do rodičovství. Zjistili, že v partnerstvích, v nichž je žena profesně vytížena, roste partnerská spokojenost u obou partnerů úměrně se zapojením otce do péče o potomka.

\section{Cíl výzkumu}

Cílem výzkumu bylo zjistit míru a subjektivně důležité aspekty partnerské spokojenosti žen v akademických povoláních a zmapovat, zda ženám stávající rozvržení času mezi osobní život (partnerství, rodinu a volný čas) a zaměstnání vyhovuje. Hlavním záměrem zde prezentované části výzkumu je odpovědět na jednu ze čtyř výzkumných otázek: Jaká je partnerská spokojenost žen $v$ akademických povoláních a které aspekty souviseji se shodou mezi partnery, partnerskou spokojeností, vyjadřováním emocí a partnerskou soudržností?

\section{Charakteristika výzkumného souboru}

Pro výběr účastnic výzkumu byla vymezena základní populace žen pracujících na univerzitách a výzkumných pracovištích v České republice. Kritéria výběru byla následující: věk v období mladé a střední dospělosti, akademická profesní dráha na státních vysokých školách nebo výzkumných pracovištích v ČR po dobu nejméně 3 let (na pozici odborná asistentka, docentka ${ }^{4}$ ) a inimálně 3 roky trvající partnerský vztah. Do výběrového souboru jsme získali 32 žen, které se ve své profesi aktivně realizují v pedagogické, vědecké a publikační činnosti. Jejich průměrný věk byl 39,2 let (rozpětí 30-52 let). Participantky jsou z Olomouckého, Jihomoravského, Středočeského, Zlínského a Pardubického kraje. Počáteční výběr vzorku byl založen na osobních kontaktech s ženami, které byly osloveny prostřednictvím informačního dopisu (16 žen), tedy metodou prostého záměrného výběru. Dalších 16 participantek jsme postupně získali metodou sněhové koule, tedy na základě doporučení již zapojených participantek. Intenzivní sběr dat probíhal od února do května 2013, za zkoumanými osobami jsme dojížděli.

Participantky se věnují těmto oborům: 7 participantek se věnuje přírodním vědám (fyzika, chemie), 7 participantek filologii (anglistika, bohemistika, germanistika), 6 participantek působí v sociálních oborech (psychologie, sociální práce), 6 participantek v oblasti pedagogiky (andragogika, didaktika, hudební výchova, pedagogika, zdravověda), 2 participantky se zabývají vědami o kultuře a umění (hudební věda, kulturní antropologie), po jedné participantce byly zastoupeny další obory - historické vědy (muzeologie), právo, filozofie a lékařství. Z hlediska akademické hierarchie se jednalo o 5 docentek a 27 odborných asistentek ( 7 z nich zahájilo

\footnotetext{
${ }^{3}$ Páry byly rozděleny na muže a ženy s tradičním postojem k genderovým rolím a na muže a ženy zastávající „rovnostářské“" rozdělení povinností a zájmů u obou pohlaví.

${ }^{4}$ Pozice profesorky nebyla ve výběrovém souboru zastoupena.
} 
habilitační řízení). Ženy byly dotazovány také na vzdělání a odborné zaměření partnera. Devět partnerů mělo akademický titul Ph.D. a $8 \mathrm{z}$ nich se nadále věnuje vědě. Znamená to, že jedna čtvrtina žen ze zkoumaného vzorku žije v akademickém páru. Patnáct partnerů mělo magisterské vysokoškolské vzdělání, z toho 3 muži byli lékaři. Tři partneři mají vysokoškolské vzdělání úrovně bakalář a pět partnerů středoškolské odborné vzdělání (obchodní akademie, vojenská akademie, automechanik). Průměrná délka partnerského vztahu byla 15 let (rozpětí 3-35 let). Většina žen (28) uzavřela s partnerem manželství, 4 ženy žijí s partnerem v nesezdaném soužití ve společné domácnosti. Ve 30 př́padech se jednalo o první manželství či nesezdané soužití, ve kterém mají participantky s partnerem děti, u zbylých 2 žen je současné manželství či nesezdané soužití druhé v pořadí. Bezdětná partnerství uvádí 7 žen, jedno dítě má s partnerem 11 žen, dvě děti 13 žen a tři děti jedna participantka.

\section{Metodologický design výzkumu}

Výzkum měl těžiště v kvalitativní metodologii, která umožnila detailnější analýzu dat a objevení nových poznatků o různých aspektech partnerského života a akademického povolání participantek. Z hlediska metod sběru a zpracování dat šlo o smíšený typ výzkumu. Výzkum byl založen na unikátním designu tzv. souběžné vnořené (zakotvené) strategie (Cresswell, 2003). Znamená to, že kvalitativní i kvantitativní data jsou sbírána souběžně, při jejich analýze jsou však data získaná jednou metodou určující (v našem případě data získaná hloubkovým rozhovorem), zatímco zbylá data mají menší prioritu, jsou významově „vnořená“ a mají spíše doplňující a obohacující charakter. Hendl (2008) zjednodušuje obdobnou výzkumnou strategii schématem $Q U A L+$ quam. Cílem této strategie je navrhnout teorii pomocí kvalitativní analýzy, přičemž kvantitativní měření se zahrne do základního rámce kvalitativního výzkumu. Konkrétně byla data získaná hloubkovými rozhovory podložena, kategorizována a validizována Škálou partnerského přizpůsobení DAS ${ }^{5}$ (Spanier, 1976). Na základě inspirace Spanierovou koncepcí partnerského prrizpůsobení byly jednotlivé aspekty partnerské spokojenosti posuzovány v souvislosti s partnerskou shodou, partnerskou spokojeností, vyjadřováním emocí a také se soudržností partnerského vztahu.

Dominantní metodou sběru dat prezentované části výzkumu byl tedy polostrukturovaný rozhovor, rovněž bylo využito anamnestických dotazníků a pozorování. Zejména rozhovor umožnil získat cenné informace o názorech, prožívání a zkušenostech cílové skupiny a porozumět jim (Hendl, 2008; Miovský, 2006). Jednotlivé otázky rozhovoru ${ }^{6}$, které se týkaly partnerské spokojenosti, jejich oblastí i podpůrných aspektů byly kladeny v souvislosti s tím, jak tyto ženy zvládají skloubení osobního života a akademické profese:

- V čem jste ve svém životě nejvíce spokojená - v kterých oblastech?

- V čem byste si př́la být více spokojená?

- Jak jste ve svém partnerském vztahu spokojena? Co je pro vás ve vztahu nejdůležitější? Co byste postrádala nejvíce, kdybyste byla sama bez partnera?

- Co myslíte, že je pro vašeho partnera ve vztahu nejdůležitější?

- Cítíte, že je vám partner ve vztahu oporou? A v čem?

\footnotetext{
${ }^{5}$ Dále $\mathrm{v}$ textu používáme pro danou metodu označení DAS. Jedná se o zkratku z původního názvu Dyadic Adjustment Scale, která byla použita např. ve výzkumu Minnotte et al. (2010).

${ }^{6}$ Otázky rozhovoru byly formulovány na základě dlouholeté zkušenosti autorek s metodou SEIQoL (O’Boyle, McGee, Joyce, 1994). Při jejich tvorbě jsme se inspirovali také uvedenými modely Spaniera (1976, 2001) a Benokraitisové (2012). Otázky týkající se souvislostí partnerské spokojenosti s náročností skloubení práce a rodinného života vychází z dosavadních výzkumů (Hochschild, Machung, 2012; Minnotte et al., 2010; Mullen, Kelley, Kelloway, 2008) a především z pozorovaných potřeb praxe.
} 
- Existuje něco, v čem vás partnerský vztah omezuje?

- Jak trávíte váš společný volný čas? Co si o vašem pracovním nasazení myslí váš partner? Je váš partner spokojen s množstvím společně tráveného času? Jak se staví k nedostatku času a dalším dopadům náročné profese na váš osobní život? Máte někdy pocit, že by vám partner něco vyčítal? Cítíte někdy ze strany partnera nepochopení?

- Jste s tím, jak se vám daří skloubit soukromý a profesní život, spokojena? Zvládáte některé situace lépe nyní, než tomu bylo v minulosti (zhodnocení současnosti a minulosti)? Co se vám daří a co by se ještě dalo zlepšit (v roli manželky/partnerky, matky, v profesní roli/pozici)?

Se souhlasem žen byly rozhovory nahrány na diktafon ${ }^{7}$, poté byl zvukový záznam převeden doslovnou transkripcí do textové podoby a z diktafonu smazán. Přepisy byly zpracovány pomocí obsahové analýzy, prostřednictvím kódování. Kód (neboli symbol) je prriřazen $\mathrm{k}$ úseku dat tak, že ho kategorizuje vzhledem k tématu a výzkumným otázkám (Hendl, 2008). Vzniklý systém kategorií a subkategorií podrobně zachycuje různé aspekty partnerské spokojenosti žen a jejich souvislosti. Kvůli zachování anonymity a ochraně citlivých údajů byla jména žen při analýze nahrazena kódem, ze kterého bylo možné odvodit pouze širší odborné zaměření (např. JAZ1 je participantka z oboru zabývajícího se filologií).

Pro měření kvality manželského soužití a partnerské shody byla z kvantitativních metod administrována Škála partnerského přizpůsobení DAS (Spanier, 1976). Jde o škálu se 32 položkami, které zjišt’ují míru partnerské shody (Dyadic Consensus), partnerské spokojenosti (Dyadic Satisfaction), vyjadřování emocí (Affectional Expression) a partnerské soudržnosti (Dyadic Cohesion). Bližší charakteristika subškál je uvedena dále v textu.

Účast ve výzkumu byla dobrovolná, participantky byly ubezpečeny o anonymitě výzkumu ${ }^{8}$ a informovány o jeho účelu. Sběr dat byl realizován na jejich pracovišti (25), v jejich domácnosti (3) nebo v kavárně (4).

\section{Výsledky 9}

Výsledky uvádíme v rámci tří úrovní analýzy dat. Aspekty pozitivně či negativně související s partnerskou spokojeností zmapované v rámci prvního a druhého výzkumného okruhu (tj. první úroveň analýzy) byly dále vztaženy $\mathrm{k}$ jednotlivým oblastem partnerského přizpůsobení podle $\mathrm{G}$. $\mathrm{B}$. Spaniera (1976) - druhá úroveň analýzy. Třetí krok analýzy spočíval v kategorizaci participantek podle skórů dosažených v DAS a v přiřazení subkategorií, které je charakterizují.

Kvalitativní analýza rozhovorů ukázala, že celkem 29 žen je ve svém partnerství spokojeno a hodnotí jej jako funkční, což koresponduje i s údaji získanými pozorováním. Tř́i zbývající participantky jsou v otázkách partnerského vztahu kritičtější. Partnerská spokojenost velmi úzce souvisí se spokojeností v profesi a s možností seberealizace, nebot' tato potřeba je navzdory většinově dominantní $(n=31)$ hodnotě mateřství a partnerství u všech participantek zastoupena.

\footnotetext{
${ }^{7}$ Průměrná délka jednoho rozhovoru byla 55 minut, jeho přepis činil průměrně 14 stran. Celkový objem textu byl tedy téměř 450 stran.

${ }^{8}$ Pro zachování anonymity záměrně vynecháváme jména, věk i konkrétní profesní zaměření participantek.

${ }^{9}$ Výsledky jsou uspořádány v systému od nejširší úrovně, což je výzkumný okruh, přes úroveň kategorií až po nejkonkrétnější subkategorie. Názvy výzkumných okruhů jsou v textu zvýrazněny tučným písmem, názvy kategorií jsou podtrženy a jednotlivé subkategorie jsou znázorněny kurzívou.
} 


\section{První úroveň analýzy: Výzkumné okruhy mapující aspekty partnerské spokojenosti}

Aspekty partnerské spokojenosti byly mapovány ve dvou výzkumných okruzích a na úrovni kvalitativní analýzy odpovídají jednotlivým subkategoriím. První okruh analýzy se týkal aspektů přispívajících $\mathbf{k}$ partnerské spokojenosti žen $\mathbf{v}$ akademických povoláních, tedy těch faktorů, které jednak souvisely s vysokými skóry v jednotlivých subškálách DAS, nebo které participantky v rozhovoru spojovaly se spokojeností ve vztahu. Identifikovali jsme celkem čtyři velké kategorie aspektů.

První kategorií byly aspekty partnerské spokojenosti na straně partnera. Zjistili jsme, že pro participantky představuje výrazný zdroj spokojenosti pozitivni a tolerantní postoj partnera kjejich profesi, pochopení a podpora ze strany partnera, oceněni a pochopení profesního úspěchu ženy, vědomí spolehlivé pomoci $v$ každodennich těžkostech $i$ závažných životních událostech a u těch participantek, které mají děti, také skutečnost, že partner je „dobrým tátou“ “jejich dětem.

V druhé kategorii s názvem aspekty partnerské spokojenosti na straně participantky jsou aspekty, které jsme zaznamenali pozorováním, či se implicitně vynořily v průběhu kvalitativní analýzy rozhovorů. Ženy spokojené v partnerství byly ve větší míře schopny uvědomovat si a oceňovat kvality svého partnera a činily tak i prostřednictvím srovnáváni s jinými ženami.

Třetí skupinu subkategorií sdružovala kategorie popisující aspekty partnerské spokojenosti vycházejících ze vzájemné kooperace partnerů. Participantky uváděly, že jejich vztah s partnerem posiluje sdilení společné aktivity, volného času a spolupráce na společném projektu ${ }^{10}$. Podstatným prvkem jejich partnerského vztahu je přátelství, sdílení a důvěra a také vzájemný respekt, úcta a pocit svobody. Obzvláště pro participantky s odlišnými vlastnostmi a očekáváními než má jejich partner je důležitým aspektem také snaha obou partnerů najít společný kompromis či prưsečik. Předmětem kompromisu mohou být ve vztahu děti, profesní nároky, volnočasové aktivity i hodnoty a budoucí směřování vztahu. Partnerský vztah z dlouhodobého hlediska nejvíce posilují ochota a snaha řšsit problémy $i$ krize, které přirozeně přicházejí, ale také společné vyrovnávání se s ečekanými těžkostmi (např́klad nemoc dítěte). Dalšími nalezenými subkategoriemi jsou: otevřená komunikace mezi partnery a rozdělení rolí v partnerství. Patnáct participantek se vyjádřilo obdobně jako ve výroku: „,̌ijeme vzajetých kolejich“, nebot' vnímají partnerský vztah jako proces překonávání počátečních nejasností, zvykání si na sebe a vzájemného přizpůsobování se.

Čtvrtá kategorie obsahuje aspekty partnerské spokojenosti vycházející ze specifik partnerských vztahů. Tři čtvrtiny participantek $(n=24)$ zdůrazňují, že jejich vztah funguje proto, že mají stejné osobnostni nastavení, životni cíle $i$ hodnoty. Velmi podobnou subkategorií vedoucí ke shodě partnerů je stejný způsob uvažování, který uvádějí především participantky s dlouhodobým partnerským vztahem. Jiné ženy $(\mathrm{n}=9)$ naopak za výhodu pro partnerský vztah považují odlišný styl uvažování i jiné osobnostní vlastnosti, nebot' partnerům umožňují vzájemně se doplňovat. Podobná situace nastává i v př́ípadě dvou subkategorií - partner pracující ve stejném oboru či podobné pracovní pozici a partner pracující v odlišném oboru. Zatímco první př́pad umožňuje partnerovi větší vhled a tedy i pochopení charakteru ženiny práce, druhý poskytuje možnost odpočinku od pracovních témat, nadhled či objektivnější pohled partnera na pracovní problémy ženy a vzájemné obohacení.

V druhém analyzovaném okruhu byly zachyceny aspekty s negativním dopadem na partnerskou spokojenost žen $\mathbf{v}$ akademických povoláních. Vztah aspektů k prožívané partnerské spokojenosti participantek byl opět, jako u předchozího výzkumného okruhu, určován srovnáváním s kvantitativními skóry v DAS a také podle explicitních a implicitních reakcí participantek $\mathrm{v}$ průběhu rozhovoru. Řadíme sem celkem 4 kategorie.

${ }^{10}$ Ženy uváděly například sběratelství, pátrání po př́buzných a předcích a sestavování rodokmenu, rekonstrukci domu, společnou práci na zahradě. 
Mezi aspekty s negativním dopadem na partnerskou spokojenost na straně partnera patří zejména nezvládnutí úspěchu ženy, který popisuje jedna účastnice výzkumu ${ }^{11}$. O svých profesních úspěších s partnerem nehovoří, vyhýbá se i tématu práce a své uspokojení nachází právě v zaměstnání, kam před partnerským nepochopením utíká. Tři participantky pocit’ují omezení vyplývající z partnerovy profese, které zapříčiňuje především nedostatek společného volného času, stres přenášený partnerem do osobního života, ale také upozaděni profese participantky kvi̊li profesi partnera.

Druhou kategorií jsou aspekty s negativním dopadem na partnerskou spokojenost na straně žen. Dvě ženy uvádějí vlastní tendenci k př́lišnému individualismu a volnomyšlenkářství, kvủli čemuž často nedoceňují př́nos partnerského vztahu pro svůj život. V menší míre byla tatáž vlastnost zmíněna i dalšími sedmi participantkami. Partnerství bývá u těchto žen za určitých okolností vnímáno jako závazek, jehož nevýhodou je nutnost se omezovat, pokud jde např́klad o práci v zahraničí a dlouhodobé zahraniční stáže nebo koníčky, volný čas a čas s práateli. Společným znakem těchto žen je i poukazování na partnerovy nedostatky, vysoce postavená hodnota nezávislosti a tendence $k$ prioritě pracovních cílů. Dalším aspektem na straně žen, který narušuje partnerskou harmonii, je dominance ženy, která se projevuje v různé míře od drobných ústupků partnera, priority ženy $\mathrm{v}$ rámci rozhodování až po radikálnější prosazování vlastních názorů a zájmů. Osmnáct participantek považuje své profesní zahlcení za aspekt s nejvíce negativním dopadem na partnerskou spokojenost. Stres při nakupení povinností a únava se v partnerském životě podepisuje na špatné náladě, malé podnětnosti v partnerství i ve volném čase, inhibici sexuálního života a v celkově menším zájmu o partnera. Tyto ženy prožívají konflikt práce - rodina (WFC).

Třetí kategorií druhého analyzovaného okruhu jsou aspekty s negativním dopadem na partnerskou spokojenost žen v rámci partnerských specifik. Věkový rozdíl partnerů se ukázal jako problematický v př́padě jedné participantky (ve zkratce je uveden v poznámce ${ }^{9}$ ). Odlišné hodnoty, životní styl i zájmové aktivity jsou vnímány jako problematické aspekty především u některých párů, které jsou spolu relativně krátce, do 5 let $(\mathrm{n}=5)$. Je možné, že u participantek stále probíhá období slad'ování se s partnerem, které se projevuje určitou disharmonií v partnerství, at' už v názorech či zájmech. U jiné participantky však negativní vnímání rozdílných hodnot s partnerem přetrvává i přes dlouhou společnou historii páru. Po zvážení širšího kontextu lze vyvodit předpoklad, že rozdílnost v osobnostních stylech není pro vztah partnerů natolik zásadní jako rozdíl v základních hodnotách. Současně záleží i na spolupůsobení dalších jmenovaných aspektů, přičemž čím více jich je negativních, tím větší je i celkový dopad na spokojenost v partnerství. Limity v rámci opory v partnerovi jsou naznačeny u čtyř participantek. Nedostatek společně tráveného času je nejčastěji zmiňovaným aspektem i u těch participantek $(n=22)$, které hovoří o tom, že jsou ve svém vztahu bez výhrad spokojeny. Jeho dopad na vztah však není tolik patrný jako u dalších jmenovaných aspektů. Jedná se spíše o oblast, o které participantky vědí, že v ní mají rezervy. Kromě práce má na společný volný čas partnerů vliv také věk dětí, př́ípadně i jejich nemoc. Krize po rodičovské dovolené je spojována s krátkodobým poklesem spokojenosti v partnerství u 18 participantek, a to i v jinak funkčních partnerských vztazích. Krize v partnerství koliduje s nástupem do zaměstnání, ve kterém často dochází ke změnám, je nutné dohánění povinností, které pro ženu představuje stres. V oblasti rodiny je zase nutné redefinovat role.

Čtvrtou kategorií jsou další aspekty s negativním dopadem na partnerskou spokojenost žen. Neprijetí ze strany tchýné, chladné vztahy a zásahy partnerovy rodiny jsou v různých nuancích (prosté konstatování, povzdech nad situací, doporučení) zmiňovány v rozhovoru s jednou participantkou. Negativní vnímání těchto ,vpádů odjinud“ je zřejmě potencováno i velkou potřebou nezávislosti. Nepřijetí participantky a především jejího profesního oboru partnerovou rodinou se

\footnotetext{
${ }^{11}$ Svého partnera potkala velmi mladá jako studentka střední školy. V průběhu času ale došlo k přesmyku rolí a z participantky se stala úspěšná akademická pracovnice, docentka s ambicemi na profesorský titul, což partner, který měl v době seznámení vyšší společenský status než jeho př́itelkyně, nikdy zcela nepřijal. S tím se sčítá i vliv partnerovy primární rodiny, která profesi partnerky neuznává a pracovní nasazení ženě vytýká.
} 
dlouhodobě promítá i do vztahu s ním. Negativní životní události jsou subjektivně vnímány natolik silně, že difúzně působí jak na partnerskou spokojenost, tak na spokojenost v pracovní oblasti. Na úrovni kvalitativní analýzy je tento dopad identifikován zejména z implicitně sdělovaných obsahů, např. hledání viníka v sobě i v partnerovi, unikání do pracovních problémů, vnímání nedostatečné podpory ze strany partnera, poukazování na rozdíly mezi vlastní osobou a partnerem, vznik konfliktu rodina - práce či vyjadřování stresu v různých oblastech života. V našem výzkumném souboru patřila $\mathrm{k}$ nejtěžším životním situacím nemoc dítěte u tří participantek a nemožnost otěhotnět $u$ jedné participantky.

\section{Druhá úroveň analýzy: Znázornění aspektů partnerské spokojenosti v souvislosti s oblastmi partnerského přizpůsobení}

Zjistili jsme, že některé z nalezených aspektů (subkategorií) souvisí s vyšší, zatímco jiné s nižší mírou partnerské spokojenosti ve škále DAS. Ne vždy je však souvislost subkategorie s mírou partnerské spokojenosti jednoznačně určitelná. Např́klad subkategorie odlišný styl uvažováni a jiné osobnostni vlastnosti může být pro partnery v jistém smyslu obohacující a doplňující, na druhou stranu - pokud se partneři liší zásadně i v hodnotách či životním stylu - může docházet k častějším sporům, což negativně působí na partnerskou harmonii.

V obrázku č. 1 jsme znázornili, kterou oblast partnerského přizpůsobení daný aspekt posiluje či narušuje. Přiřazování aspektů k oblastem partnerského přizpůsobení probíhalo na základě porovnávání skórů dosažených v DAS s výskytem subkategorií u participantek. Dalším kritériem pro přiřazení byla obsahová souvislost aspektu s konkrétní subškálou DAS. Podle Spaniera (2001) subškála Partnerské shody ukazuje míru souhlasu partnerů v oblasti náboženství, způsobu odpočinku, přátel, plnění domácích povinností a společně stráveného času. Subškála Partnerské spokojenosti měří, v jaké míře je ve vztahu partnerů prrítomná tenze a jak jsou partneři schopni se s ní vypořádat. Vyšší skór v této subškále indikuje spokojenost s partnerským vztahem a závazek v něm pokračovat. Subškála Vyjadřování emocí poukazuje na spokojenost se vzájemným vyjadřováním lásky a se sexuálním životem. Poslední subškála hodnotí společné zájmy a sdílené činnosti, které posilují stabilitu vztahu. Např́íklad subkategorie Sdílení společné aktivity, volného času a spolupráce na společném projektu se vyskytovala u žen s vysokým skórem v subškále Partnerské soudržnosti ( $T$ - skór vyšší než 60) a současně odpovídá jejímu obsahu. 
Obr. 1. Aspekty partnerské spokojenosti získané kvalitativní analýzou a jejich obsahová souvislost s jednotlivými oblastmi partnerského přizpůsobení v DAS

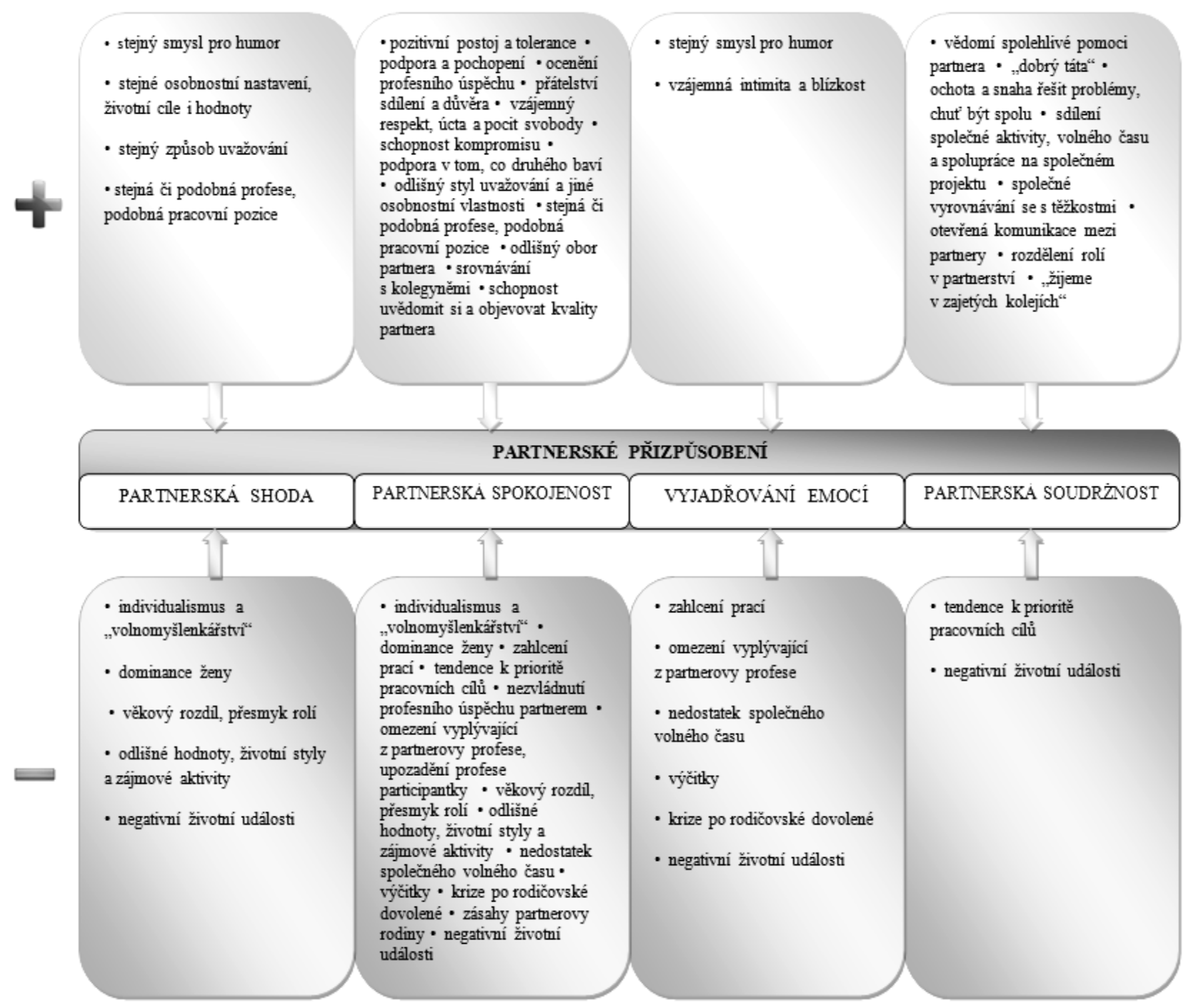

\section{Třetí úroveň analýzy: Kategorizace participantek podle celkového skóru DAS a výskytu aspekti̊}

Ženy byly rozděleny do tří skupin podle dosažené hodnoty partnerského přizpůsobení ve škále DAS a byly k nim prriřazeny subkategorie (aspekty partnerské spokojenosti) nalezené při analýze rozhovorů.

Malé partnerské přizpůsobení (T-skór $\mathrm{DA}=30$ až 44) vykazovalo celkem 5 participantek (Tab. 1). Jedná se o poměrně homogenní skupinu žen. Nízká míra partnerského přizpůsobení je u čtyř participantek způsobena zřejmě aktuálním obdobím náročným především z osobního hlediska, zatímco situace v profesní oblasti má dopad až sekundární. Čtyři ženy prožívají negativní životní událost, která se dotýká jejich rodičovství (nemoc či problémy dítěte, nebo nemožnost otěhotnět). To má vzhledem ke skutečnosti, že rodičovství je prioritou všech těchto žen, velký dopad i na jejich partnerský vztah. Nejnižší hodnota partnerského přizpůsobení $(\mathrm{DA}=30)$ se 
vyskytuje u participantky zmíněné v poznámce ${ }^{9}$. Pro stručnost uvádíme u ní nalezené subkategorie jen pod označením „INDIVIDUÁLNĚ“; dále u ní figuroval individualismus a tendence k nezávislosti, ke které byla participantka svou primární rodinou vedená. Ženy této kategorie spojuje pocit nepochopení ze strany partnera, jejich vlastní dominantní role v partnerství, ale také oboustranná menši schopnost dělat v partnerství kompromisy, což je vzhledem k popisovaným odlišným vlastnostem a životním stylưm partnerů nezbytné. Kromě jedné participantky partnerský vztah nebo rodičovství vždy zasahují do profesního života žen ve smyslu omezení či neporozumění, proto je pro tyto ženy typický vznik konfliktu rodina - práce. Pokud ženy mají možnost, utíkají do světa práce před nepř́ijemnostmi v osobním životě. Stabilita těchto partnerství je udržována společnou snahou a schopností partneru přenést se přes životni těžkosti $(\mathrm{n}=4)$ a také zřejmě $\mathrm{v}$ důsledku dlouhé společné historie partnerů $(\mathrm{n}=1)$.

Tab. 1: Společné subkategorie u participantek ${ }^{12}$ s DA $=30$ až 44

\begin{tabular}{l|l}
\hline $\begin{array}{l}\text { Pozitivní } \\
\text { aspekty } \\
\sum=2\end{array}$ & ochota a snaha řešit problémy (3); společné vyrovnávání se s těžkostmi (2) \\
\hline $\begin{array}{l}\text { Negativní } \\
\text { aspekty }\end{array}$ & $\begin{array}{l}\text { individualismus a volnomyšlenkářství (5); dominance na straně ženy (4); tendence } \\
\text { k prioritě pracovních cílů (4); nepochopení ze strany partnera (4); negativní životní } \\
\text { události (4), odlišné hodnoty a osobnostní styly (2) } \\
\text { INDIVIDUÁLNĚ: věkový rozdíl a přesmyk rolí; nezvládnutí profesního úspěchu } \\
\text { partnerem; upozad'ování profese participantky; výčitky; zásahy partnerovy rodiny a } \\
\text { nepřijetí ze strany tchýně }\end{array}$ \\
\hline
\end{tabular}

Průměrné partnerské přizpůsobení (T-skór $\mathrm{DA}=47$ až 55) vykazuje 19, a tedy i nejvíce participantek (Tab. 2). Kromě tří participantek, které jsou aktuálně na rodičovské dovolené, všechny ženy sdělují aktuální zahlcení prací a konflikt typu práce - rodina. Patří sem téměř všechny participantky, které mají i další funkci na univerzitě (funkce proděkanky, vedoucí ústavů či kateder) nebo jsou docentkami. V rozhovorech sdělují partnerskou spokojenost, tolerantní a podporující postoj partnera. Dá se tedy předpokládat, že výrazná únava, dlouhodobý stres a náročné slad'ování osobního a profesního života zřejmě souvisí s percepcí partnerského přizpůsobení. Přesto si v osobním životě všímají především kladů, jsou v něm spokojenější než v oblasti práce, kde spatřují mnohé nedostatky a rezervy. Partnerský vztah pro ně představuje klidné útočiště před těmito nároky. Všímají si kvalit svého partnera a umí je ocenit. Partner je pro ně „dobrým otcem “ $\mathrm{v}$ př́ípadě, že s ním mají děti. Je pro ně i dưvěrným přitelem, se kterým sdílejí své problémy. Jinak se jedná o dost heterogenní skupinu, která by se ovšem dala rozdělit na dvě homogennější skupiny. Patří sem jak participantky s dlouhodobými partnerskými vztahy, tak se vztahy v našem souboru nejkratšími $(\mathrm{n}=4)$.

První skupinu reprezentují ženy, které shodují na tom, že jejich partnerský vztah se vyvinul od intenzivní zamilovanosti s výrazným vyjadřováním pocitů do klidnější fáze charakteristické důvěrou, stabilitou a kohezí posílenou překonáním partnerských i životních krizí, zpravidla po

${ }^{12} \sum=$ počet aspektů pro danou skupinu žen. Čísla v závorce za jednotlivými subkategoriemi udávají počet žen v dané skupině, které takto odpovídají. 
rodičovské dovolené. Tyto participantky mají děti v různém věku. Se svým partnerem žijí v ,,zajetých kolejích“, našli si spolu tedy způsob, jak efektivně rozdělit a skloubit role v domácnosti a sladit své individuální odlišnosti v rámci zájmů, vlastností, ale i očekávání od života. Do druhé skupiny žen řadíme ty s kratšími partnerskými vztahy, v nichž aktuálně probíhá obdobi slad'ování životních stylů, očekávání od života a profesního života každého z partnerů s osobním časem. Tato skupina se od první liší i v rámci subškál dotazníku DAS - zatímco druhá skupina skóruje nejvíce v subškále Vyjadřování emocí, u participantek první skupiny jsou zde výsledky vzhledem $\mathrm{k}$ průměru skupiny nejnižší, což může být vysvětleno právě délkou partnerského vztahu. Ženy z obou skupin hovoří o tom, že se s partnerem ve způsobu uvažování i osobnostních vlastnostech odlišují, což vyžadovalo či u participantek s kratším vztahem stále vyžaduje již zmíněné vzájemné slad'ování a schopnost kompromisu. Tyto odlišnosti však párům umožňují vzájemné doplňování a kooperaci, což má pozitivní dopad i na vzájemnou regulaci pracovních aktivit. V základních hodnotách se však povětšinou shodují.

Tab. 2 : Společné subkategorie u participantek s DA = 47 až 55

\begin{tabular}{|c|c|}
\hline $\begin{array}{l}\text { Pozitivní } \\
\text { aspekty } \\
\quad \sum=11\end{array}$ & $\begin{array}{l}\text { rozdělení rolí v partnerství (19); podpora a pochopení (16); schopnost kompromisu } \\
\text { (16); přátelství, sdílení a důvěra (15); schopnost uvědomit si kvality partnera (12); } \\
\text { „̌̌ijeme v zajetých kolejích“ (11); pozitivní a tolerantní postoj partnera (10); dobrý táta } \\
\text { (10); ocenění a podpora partnerem v profesním úspěchu (10); odlišný styl uvažování a } \\
\text { osobnostní vlastnosti (8); ochota a snaha řešit problémy (7) }\end{array}$ \\
\hline $\begin{array}{l}\text { Negativní } \\
\text { aspekty } \\
\sum=3\end{array}$ & $\begin{array}{l}\text { krize po rodičovské dovolené (13); zahlcení prací (11); odlišné hodnoty, životní styly a } \\
\text { zájmové aktivity (5) }\end{array}$ \\
\hline
\end{tabular}

Vysokého partnerského přizpůsobení (T-skór DA = 56 až 60) dosáhlo v hodnocení dotazníku DAS celkem 8 participantek (Tab. 3). Jejich partnerství jsou bud' zatím bezdětná a v nejbližší době rodičovství neplánují nebo jej neplánují vůbec $(n=4)$. Kromě toho sem řadíme páry dlouhodobě spokojené, které vysoce skórují právě v subškále Partnerské soudržnosti $(n=4)$. Celá skupina participantek dosahuje s partnerem vysoké shody. Participantky hovoří o vzájemném obohacování a doslova souznění, což ilustruje i výrok participantky týkající se strategie jejího partnera při řešení důležitých profesních rozhodnutí: „Já už se tě ani nemusím ptát, už vím, co bys mi odpověděla, natolik Tě znám. " Ženy mluví nejen o podobných hodnotách s partnerem, ale i o stejném způsobu trávení volného času, podobném uvažování i smyslu pro humor, přitom však akceptují partnerovu potřebu určité svobody a tolerance a vzájemně se podporuji v tom, co druhého baví a v čem nachází seberealizaci. Zmiňované krize se týkají spíše profesního života než partnerských problémů. Dopad profesního zatížení svého či partnerova byl pouze krátkodobý v období po rodičovské dovolené, obdobně jako u předchozí kategorie žen, a podařilo se jej úspěšně překonat, což vedlo k posílení vztahu ve smyslu nalezení společných kompromisů a nabytí vědomí, že je možné se na partnera $v$ životě spolehnout. Se svými partnery se seznámily, když byly už obdobně profesně zatížené, což usnadnilo vzájemné slad'ování. Partner je vnímán jako výrazná podpora v jejich životě a nejbližši prritel, se kterým sdílejí své aktuální (především profesní) těžkosti a kterému důvěřují. Na základě analýzy rozhovorů lze konstatovat, že se do pozitivního prožívání partnerského života promítá i schopnost efektivně zvládat pracovní zátěž a úspěšně plánovat pracovní aktivitu a oddělit ji od osobního života, či ji zapojit tak, že to oběma partnerům vyhovuje. 
Tab. 3 : Společné subkategorie u participantek s DA = 56 až 60

\begin{tabular}{l|l}
\hline $\begin{array}{l}\text { Pozitivní } \\
\text { aspekty }\end{array}$ & $\begin{array}{l}\text { pozitivní a tolerantní postoj partnera (8); podpora a pochopení (8); vědomí spolehlivé } \\
\text { pomoci (8); uvědomit si kvality partnera (8); přátelství, sdílení a důvěra (8); vzájemný }\end{array}$ \\
$\qquad=12$ & $\begin{array}{l}\text { respekt, úcta a pocit svobody (8); společný kompromis (8); stejný způsob uvažování } \\
\text { (7); podpora v tom, co druhého baví (6); stejný smysl pro humor (6), společné aktivity, } \\
\text { volný čas a spolupráce na společném projektu (5); ocenění a podpora partnerem } \\
\text { v profesním úspěchu (4) }\end{array}$ \\
\hline $\begin{array}{l}\text { Negativní } \\
\text { aspekty }\end{array}$ & krize po rodičovské dovolené (3) \\
\hline
\end{tabular}

\section{Diskuze}

Psychologické aspekty zvládání a úspěšného skloubení akademické profese ženy a jejího osobního života v České republice zkoumány doposud nebyly. Otázkami genderového znevýhodnění a zvládání nároků akademického povolání se aktuálně zabývají především čeští sociologové (Červinková, 2007; Havelková, 2007; Linková, 2007; Šaldová, 2007; Tupá, 2007; Vohlídalová, 2011).

V zahraniční odborné literatuře lze najít psychologické studie týkající se partnerské spokojenosti s ryze kvantitativním výzkumným designem a z hlediska výzkumného souboru obecněji zaměřené na dvoukariérová partnerství (Gilbert, 1993; Hall, MacDermid, 2009; Holmstrom, 1972; PepitoneRockwell, 1980; Rapoport, Rapoport, 1969; Rapoport, Rapoport, 1976; Yogev, 1982). U nás se vyskytují studie partnerské spokojenosti u obou partnerů v dvoukariérových partnerstvích, ale bez bližší specifikace jejich profesí, a to pouze v rámci nepublikovaných absolventských prací (Fajmonová, 2009; Zbíralová, 2003).

Výběrové soubory podobné našemu, konkrétně dvojice působící v akademické sfére, figurují zase ve výzkumech zaměřených téměř výhradně na téma rolového konfliktu a zvládání nároků profese (Fox, Fonseca, Bao, 2011; Jacobs, Winslow, 2004; Wyss, Tai, 2010). V prípadě těchto studií je však třeba brát na zrretel odlišný historický kontext a společenské podmínky. Srovnatelnost výzkumů je obtížná také proto, že se studie se liší zaměřením, metodami a zmíněnými charakteristikami výběrového souboru. Většinou se jedná o studie kvantitativního charakteru zaměřené na dílčí osobnostní charakteristiky žen vědkyň, genderovou nerovnost akademického prostředí a genderovou politiku (Jacobs, Winslow, 2004) a zvládání stresu z rolového konfliktu (Clark, 2001; Fox, Fonseca, Bao, 2011; Wyss, Tai, 2010; Zhao, Settles, Sheng, 2011).

Naše výsledky mohou dosavadní výzkumná zjištění kvantitativní povahy spíše doplňovat o nové poznatky, než potvrzovat či vyvracet. Design výzkumu a použití souběžné vnořené strategie (Cresswell, 2003) nám umožnilo roztř̌íění jednotlivých aspektio/subkategorií na základě oblastí partnerského přizpůsobení podle G. B. Spaniera (1976) a vytvoření kategorizace žen podle dosahované hodnoty partnerského přizpůsobení a zastoupení jednotlivých aspektů. Získaná kvalitativní data tímto způsobem nabyla na validitě.

Ve shodě s J. Mullenem, E. Kelley a E. K. Kellowayem (2008) můžeme konstatovat, že i u našeho výběrového souboru participantek je zřejmé propojení oblasti partnerství, práce a rodičovství. Vzhledem k prioritě rodičovství u všech žen majících děti byla důležitým aspektem partnerské 
spokojenosti také skutečnost, zda je partner současně i dobrým otcem jejich dětí. Jak uvádí i Ch.-Y. S. Lee a W. J. Doherty (2007), ve vztahu partnerů se ve značné míre odráží to, jaký má otec ke svým dětem vztah a do jaké míry se jim ve svém volném čase věnuje.

Ačkoliv je partnerství podle výpovědí participantek považováno za fungující a št’astné, objevují se jednotlivé aspekty, které se do míry prožívané spokojenosti promítají negativně. V rámci kategorizace žen na základě dosaženého skóre v DAS to nejlépe dokládají výsledky druhé skupiny žen se skórem DA = 47 až 55. Hlavními aspekty ohrožujícími partnerskou spokojenost této skupiny žen jsou především profesní přetížení a vznik konfliktu práce - rodina. Stejně jako výsledky J. Mullena, E. Kelleye a E. K. Kellowaye (2008) i naše participantky popisují zásahy pracovního života do osobní sféry, zvýšený stres $\mathrm{v}$ náročných obdobích přenášený na partnera a projevující se menším výkonem v domácnosti a menší podnětností v partnerství. Korektivním faktorem je $\mathrm{v}$ těchto př́padech osobnost partnera, který je osobnostně vyspělý, soběstačný a samostatný, schopný postarat se nejen sám o sebe, ale i o celou domácnost a o děti v př́ípadě absence ženy. Ve srovnání s jinými výše zmíněnými výzkumy zabývajícími se participací mužů na domácích povinnostech (Hall, MacDermid, 2009; Hochschildová, 1997), jsou partneři žen v našem výzkumu vnímaní jako angažovanější, ochotnější a více nápomocní, navíc tak činí zcela přirozeně. Zde však mohlo dojít k určitému zkreslení, nebot' v našem výzkumu byly zapojeny pouze ženy, nikoliv oba partneři.

Z rozhovorů dále vyplynulo, že se některé participantky shodují na pozitivním př́nosu stejných hodnot, vlastností a zájmů, současně však jiné ženy oceňovaly i osobnostní a zájmovou rozdílnost. $\mathrm{S}$ přihlédnutím k námi vytvořené kategorizaci můžeme konstatovat, že stejné hodnoty, způsob uvažování, ale i smysl pro humor jsou na rozdíl od odlišností ve jmenovaných oblastech zastoupeny u žen s nejvyššími skóry DAS (DA = 56 až 60). Tato zjištění tedy potvrzují závěry $\mathrm{N}$. J. Benokraitisové (2012). Zcela odlišné hodnoty a životní směřování nebyly v našem výzkumu zastoupeny. Význam rozdílného způsobu uvažování, odlišných vlastností a zájmů není vzhledem k partnerské spokojenosti jednoznačný. Participantky oceňují, že se díky této skutečnosti s partnerem doplňují, na druhé straně ale vzniká prostor pro názorové neshody a konflikty. Důležitější proto bude spíše ochota se přizpůsobit, přristoupit na kompromisy a hledat společné průsečíky (viz Benokraitis, 2012; Olson, Olson, 2000). Určité vysvětlení nabízí fáze partnerského vztahu u participantek v kategorii s DA $=47$ až 55. Participantky se vztahy kratšími (4-5 let) ještě na odlišnosti s partnerem narážejí a probíhá vzájemné slad’ování rolí, životních cílů i společných aktivit. Participantky s dlouhodobými vztahy často zmiňují zvládnutí kompromisu a ,život v zajetých kolejích“, který oběma partnerům vyhovuje. Projevuje se jednak v oboustranné snaze respektovat pracovní nasazení partnera, ale také ve vycházení si vstříc v rámci trávení volného času.

Subjektivně nižší partnerská spokojenost je zapříčiněna především nepochopením ze strany partnera, nepřijetím ženina profesního úspěchu a neuznáním jejího oboru, které žena cítí i v jeho širší rodině. Upozorňování na nedostatky, nízká úroveň podpory a přesvědčení ženy, že své profesní úspěchy musí před partnerem skrývat, jsou aspekty přispívající k partnerské nespokojenosti, ale také $\mathrm{k}$ potřebě utíkat před partnerovým nepochopením do práce a upínat se na ni. I v našem výzkumu tedy narážíme na fenomén umělého udržování přirozenosti genderových rolí a nepříznivého vnímání kariéry partnerem (Křížková, 2002; Kř̌̌žková, Helšusová, 2002). Ačkoliv naprostá většina žen uvádí jako nejdůležitější hodnotu rodinu a partnerství, nutnost přizpůsobit a mezit svou profesní dráhu kvůli prioritní kariéře partnera frustruje potřebu seberealizace, která má dopad i na celkovou životní spokojenost participantky, což opět doplňuje zjištění K. Minnotteové et al. (2010).

Partnerská spokojenost podle našich závěrů souvisí s genderovou perspektivou, kterou žena zaujímá $\mathrm{v}$ rámci pracovních povinností, ale především $\mathrm{v}$ roli partnerky. Naše závěry korespondují s výzkumem K. Minnotteové a jejího výzkumného týmu (2010), kteří potvrdili, že ženy zastávající tradiční genderové postoje a role v menší míře vnímají dopad konfliktu práce - rodina na 
partnerskou spokojenost a jejich partnerská spokojenost je vyšší. U žen s vůbec nejnižší mírou partnerského přizpůsobení (DA = 30 až 44) v našem vzorku se projevovala nadměrná tendence $\mathrm{k}$ individualismu, silně protěžovaná hodnota nezávislosti a snaha být ve vztahu dominantní. V životě těchto žen existují momenty, ve kterých nedoceňují přínosnost partnerského vztahu a mají kvůli partnerskému vztahu pocit omezení.

Jako největší prozatímní limit našeho výzkumu vnímáme absenci partnerů žen ve výzkumném souboru. Vzhledem k nedostatku výzkumů na toto téma jsme se však rozhodli nejdříve zmapovat danou problematiku z pohledu samotných žen. Další zamýšlenou variantou je zaměřit se na cílovou skupinu žen, kterým se partnerský vztah rozpadl, nebo v něm nejsou spokojené. Obě zvažované možnosti, u nichž předpokládáme ještě větší náročnost získávání zkoumaných osob, však podle logiky postupu následují až po tomto výzkumu.

\section{Závěr}

Funkční partnerský vztah usnadňuje ženám pracujícím v akademickém povolání nejen slad’ování rodinného, profesního a osobního života, ale i samotné zvládání požadavků profese. Vztahy založené na vzájemném souznění, úctě, oboustranném respektu a kompromisu vykazují větší stabilitu a harmonii. Nejvíce spokojené ženy hovoří o společných hodnotách, vlastnostech i zájmech s partnerem, který je velmi tolerantní a je pro ženu oporou v osobních i pracovních záležitostech. Nejčastěji uváděným aspektem narušujícím partnerskou spokojenost je konflikt práce - rodina (konflikt WFC), který postihuje i velmi funkční vztahy. Zásadním negativním faktorem zasahujícím do partnerské spokojenosti je nepochopení a nepřijetí profesního úspěchu ženy partnerem a také nadměrná dominance a individualismus na straně žen, který v participantkách vyvolává pocit omezení partnerem a vede je k protěžování profesních zájmů.

Výzkumná zjištění budou podkladem pro formulaci praktických doporučení, která by podobně vytíženým ženám pracujícím i mimo akademickou oblast umožnila efektivnější slad'ování obou hlavních životních oblastí.

Zpracování článku bylo umožněno díky účelové podpoře na specifický vysokoškolský výzkum udělené roku 2013 Univerzitě Palackého v Olomouci Ministerstvem školství, mládeže a tělovýchovy ČR (SGS IGA, FF_2013_021).

\section{Literatura}

Benokraitis, N. J. (2012). Marriages and families. Changes, choices and constraints ( $7^{\text {th }}$ Ed.). Prentice Hall: Pearson Education.

Bierzová, J. (2006). Rozdělení domácích prací a péče o děti. In A. Kř́žková, H. Maříková, H. Hašková, \& J. Bierzová, Pracovni a rodinné role a jejich kombinace v životě českých rodičũ: plány versus realita (19-26). Praha: Sociologický ústav AV ČR.

Clark, S. C. (2001). Work cultures and work/family balance. Journal of Vocational Behavior, 58(3), 348365.

Coser, R. L., \& Rokoff, G. (1971). Women in the occupational world: Social disruption and conflict. Social Problems, 18(4), 535-554.

Cresswell, J. W. (2003). Research design. Qualitative, quantitative, and mixed method approaches. Thousand Oaks: Sage Publications.

Čermáková, M., Hašková, H., Kř́̌̌̌ková, A., Linková, M., \& Maříková, H. (2002). Podmínky harmonizace práce a rodiny $v \check{C} R$. Praha: Sociologický ústav AV ČR. 
Čermáková, M., Maříková, H., Šanderová, J., \& Tuček, M. (2000). Proměny současné české rodiny. Praha: Sociologické nakladatelství.

Červinková, A. (2007). Na vědecké dráze: příští zastávka „rodičovství“. In K. Šaldová (Ed.), Cesty labyrintem: o vědecké profesi, soukromém životě a jejich propojováni (26-35). Praha: Sociologický ústav AV ČR.

Decarli Valdrová, J., et al. (2004). ABC feminismu. Brno: Nesehnutí.

Dudová, R. (2006). Partnerský život a slad’ování práce a rodiny v páru u žen a mužů v manažerských pozicích. Gender, rovné přiležitosti, výzkum, 7(2), 58-62.

Fajmonová, V. (2009). Psychologické aspekty dvoukariérového manželství. (Nepublikovaná diplomová práce). Olomouc: Univerzita Palackého.

Fox, M. F., Fonseca, C., \& Bao, J. (2011). Work and family conflict in academic science: Patterns and predictors among women and men in research universities. Social Studies of Science, 41(5), 715-735.

Gareis, K. C., Barnett, R. Ch., Ertel, K. A., \& Berkman, L. F. (2009). Work-family enrichment and conflict: Additive effects, buffering, or balance? Journal of Marriage and Family, 71, 696-707.

Gilbert, L. A. (1993). Two careers/one family: The promise of gender equality. Newbury Park: Sage Publications.

Gröpel, P. (2006). Rovnováha životných oblastí vo vzt'ahu k naplnenosti potrieb a spokojnosti so životom. Československá psychologie, 50, 71-83.

Gröpel, P. (2007). On the theory of life balance. Saarbrücken: VDM Verlag.

Gröpel, P., \& Dovičovičová, K. (2012). Pracovná flexibilita ako nástroj zvyšovania rovnováhy životných oblastí: Je flexibilita vhodná naozaj pre každého? Československá psychologie, 56, 56-63.

Gröpel, P., \& Kuhl, J. (2009). Work-life balance and subjective well-being: The mediating role of need fulfilment. British Journal of Psychology, 100, 365-375.

Hakim, C. (2000). Work - lifestyle choices in the $21^{\text {st }}$ century. Preference theory. Oxford: University Press.

Hall, D. (1972). A model of coping with role conflict. Administrative Science Quarterly, 17, 471-486.

Hall, S. S., \& MacDermid, S. M. (2009). A quantitative typology of dual-earner couples: Unanswered questions about circumstances, motivations, and outcomes. Journal of Family and Economic Issues, 30, 215-225.

Hartmut, K. (2006). Ženy-muži: Genderové role, jejich pưvod a vývoj. Praha: Portál.

Havelková, H. (2007). Problém takzvané harmonizace: náprava nezamýšlených důsledků moderní společnosti. In K. Šaldová (Ed.), Cesty labyrintem: o vědecké profesi, soukromém životě a jejich propojování (10-17). Praha: Sociologický ústav AV ČR.

Hendl, J. (2008). Kvalitativni výzkum. Základni teorie, metody a aplikace. Praha: Portál.

Hochschild, A. (1997). The time bind: When work becomes home and home becomes work. New York: Metropolitan Books.

Hochschild, A., \& Machung, A. (2012). The second shift. Working families and the revolution at home. New York: Penguin Books.

Holmstrom, L. L. (1972). The two-career family. Cambridge: Schenkman.

Jacobs, J. A., \& Winslow, S. E. (2004). The academic life course, time pressures and gender inequality. Community, Work \& Family, 7(2), 143-161.

Křǐžková, A. (2002). Životni strategie manažerek: připadová studie. Praha: Sociologický ústav AV ČR. 
Křižková, A., \& Helšusová, L. (2002). Sociálni kontext žen pracujicich v řidicích pozicích: analýza odlišnosti životnich postojů a názorů mužũ a žen v české společnosti v závislosti na jejich pracovním postavení. Praha: Sociologický ústav AV ČR.

Lee, Ch.-Y. S., \& Doherty W. J. (2007). Marital satisfaction and father involvement during the transition to parenthood. Fathering, 5(2), 75-96.

Linková, M. (2007). Instituce, vědní politiky a gender, aneb jak se z jasně narýsované cesty stává labyrint. In K. Šaldová (Ed.), Cesty labyrintem: o vědecké profesi, soukromém životě a jejich propojování (18-25). Praha: Sociologický ústav AV ČR.

Minnotte, K., Minnotte, M., Pedersen, D., Mannon, S., \& Kiger, G. (2010). His and her perspectives: Gender ideology, work-to-family conflict, and marital satisfaction. Sex Roles, 63(5/6), 425-438.

Miovský, M. (2006). Kvalitativní př́stup a metody v psychologickém výzkumu. Praha: Grada Publishing.

Mullen, J., Kelley, E., \& Kelloway, E. K. (2008). Health and well-being outcomes of the work-family interface. In K. Karabik, D. S. Lero, \& D. L. Whitehead (Eds.), Handbook of work-family integration. Research, theory and best practices (191-214). London: Academic Press.

Netemeyer, R. G., Boles, J. S., \& McMurrian, R. (1996). Development and validation of work-family conflict and family-work conflict scales. Journal of Applied Psychology, 81, 400-410.

O’Boyle, C. A., McGee, H., Joyce, C. R. B. (1994). Quality of life: assessing the individual. In G. L. Albrecht, \& R. Fitzpatrick, R., Advances in Medical Sociology. Duality of life in health care (159-180). Greenwich: JAI Press.

Olson, D. H., \& Olson A. K. (2000). Empowering couples: Building on your strengths. Minneapolis: Life Innovations.

Pepitone-Rockwell, F. (1980). Dual career couples. Beverly Hills: Sage Publications.

Plaňava, I. (1994). Komponenty a procesy fungující rodiny a manželství. Československá psychologie, 38, 114.

Rapoport, R., \& Rapoport, R. N. (1969). The dual-career family: a variant pattern and social change. Human Relations, 22, 3-29.

Rapoport, R., \& Rapoport, R. N. (1976). Dual Career Families Re-examined. London: Martin Robertson \& Company Ltd.

Rusbult, C., Verette, J., Whitney, G., Slovick, L., \& Lipkis, I. (1991). Accommodation process in close relationships: Theory and preliminary empirical evidence. Journal of Personality and Social Psychology, 60, 53-78.

Rusbult, C. (1993). Understanding responses to dissatisfaction in close relationships: The exit, voice, loyalty and neglect model. In S. Worchel \& J. Simpson (Eds.), Conflict between people and groups: Causes, processes, and resolutions (30-59). Chicago: Nelson-Hall.

Spanier, G. B. (1976). Measuring dyadic adjustment: New scales for assessing the quality of marriage and similar dyads. Journal of Marriage and the Family, 38, 15-28.

Spanier, G. B. (2001). Dyadic adjustment scale. User's manual. Toronto: MHS.

Stanley, S. M. (2007). Assessing couple and marital relationships: Beyond form and toward a deeper knowledge of function. In L. M. Casper, \& S. L. Hoffereth (Eds.), Handbook of measurement issues in family research (85-100). New Jersey: Lawrence Erlbaum \& Associates.

Šaldová, K. (Ed.) (2007). Cesty labyrintem: O vědecké profesi, soukromém životě a jejich propojování. Praha: Sociologický ústav AV ČR.

Tupá, B. (Ed.). (2007). Dámský gambit: Zahájení akademické dráhy. Praha: Sociologický ústav AV ČR. 
Vohlídalová, M. (2006). Pracovní život a partnerské rozchody. Socioweb: sociologický webzin [online], 12, 5-7. [cit. 2013-12-05]. ISSN 1214-1720. Dostupné z:

$<$ http://www.socioweb.cz/index.php?disp=temata\&shw=238\&lst=120>.

Vohlídalová, M. (2011). „Není možné přerušit práci a říct, že tady 4 roky nebudu“: o strategiích kombinace práce a rodičovství ve vědecké profesi. Socioweb: sociologický webzin [online], 9, 3-4. [cit. 2013-12-05]. ISSN 1214-1720. Dostupné z: <http://www.socioweb.cz/index.php?disp=temata\&shw=383\&lst=118>.

Voydanoff, P. (2005). Toward a conceptualization of perceived work-family fit and balance: A demands and resources approach. Journal of Marriage and Family, 67, 822-836.

Wyss, V. L., \& Tai, R. H. (2010). Conflicts between graduate study in science and family life. College Student Journal, 44(2), 475-491.

Yogev, S. (1982). Happiness in dual career couples: Changing research, changing values. Sex Roles, 8(6), 593-605.

Zbíralová, B. (2003). Psychologická analýza profesní a mateřské role ženy. Nepublikovaná diplomová práce. Olomouc: Univerzita Palackého.

Zhao, J., Settles, B. H., \& Sheng, X. (2011). Family-to-work conflict: Gender, equity and workplace policies. Journal of Comparative Family Studies, 42(5), 723-738.

Poděkování patří studentkám Šárce Daňkové a Kláře Šiškové za pomoc při transkripci rozhovorů.

\section{O autorkách}

PhDr. Veronika Očenášková vystudovala jednooborovou psychologii na Univerzitě Palackého v Olomouci. Na Katedře psychologie Filozofické fakulty Univerzity Palackého v Olomouci působí v současné době jako interní doktorandka. Ve své disertaci pracuje na tématu partnerské spokojenosti žen v akademických povoláních. Výzkumně se zabývala také problematikou singles, kyberšikany a pěstounské péče. Pracuje jako školní psycholožka na střední škole.

\section{Kontaktní údaje}

Adresa: Katedra psychologie FF UP, Křížkovského 10, 77180 Olomouc

E-mail: veronika.ocenaskova01@upol.cz

Doc. PhDr. Irena Sobotková, CSc. vyučuje na Katedře psychologie Filozofické fakulty Univerzity Palackého v Olomouci. Zaměřuje se hlavně na psychologii rodiny a vývojovou psychologii. V praxi se dlouhodobě věnuje poradenství, metodické činnosti a vzdělávání v oblasti náhradní rodinné péče. I její výzkumné a publikační aktivity se týkají psychologie rodiny, partnerství a rodičovství.

\section{Kontaktní údaje}

Adresa: Katedra psychologie FF UP, Křížkovského 10, 77180 Olomouc

E-mail: irena.sobotkova@upol.cz

\footnotetext{
Očenášková, V., \& Sobotková, I. (2014). Partnerská spokojenost žen pracujících v akademických povoláních. E-psychologie [online], 8, 3, 14-32 [cit. vložit datum citování]. Dostupný z WWW: <http://e-psycholog.eu/pdf/ocenaskova_sobotkova.pdf>. ISSN 1802-8853.
} 